\title{
The Research on Classifying Denitrification Electricity Price Based on Method of Operating Period Electricity Price and DEA
}

\author{
Jianguo Zhou ${ }^{1}$, Xiaodan Pan $^{2}$, Lin Meng ${ }^{2}$ \\ ${ }^{1}$ Department of power engineering, North China Electric Power University, Hebei Province, China \\ ${ }^{2}$ Department of Business and management, North China Electric Power University, Hebei Province, China \\ xiaodaidandan@126.com, menglinh@126.com
}

\begin{abstract}
In this paper, a vision of classifying denitrification electricity price of various denitrification unit based on different relative efficiency of denitrification is put forward. First of all, take 46 denitrification unit sample of randomly selected nationwide to be the calculation object, using the method of operating period electricity price to calculate denitrification electricity price of each sample; and then regarding total costs (operating costs + financial expenses + depreciation expense) of each denitrification unit as inputs, removal amount as output, use DEA to calculate the relative efficiency of each sample project; finally, according to the calculated relative efficiency use cluster analysis to classify denitrification sample, so as to determine the classified denitrification electricity price. Classifying the denitrification unit based on the relative efficiency is the beneficial trial of denitrification electricity price classification pricing, and this classification will help to solve denitrification electricity price compensation going "inequality", also it is of great significance to enhance denitrification efficiency.

Index Terms - DEA, the method of operating period electricity price, classifying denitrification electricity price.
\end{abstract}

\section{Introduction}

By 2020, China will become the first major nitrogen oxides $\left(\mathrm{NO}_{\mathrm{X}}\right)$ emissions country [1]. $70 \%$ of $\mathrm{NO}_{\mathrm{X}}$, which is discharged by China, comes from burning coal, and the coals fired by power generation account for $70 \%$ of the nation's [2]. Concerning those generation enterprises who are required to put into denitrification device, their cost of power generation is increasing, so the country should give some financial compensation to them, and the compensation part on the basis of the normal electricity price is called denitrification electricity price.

At present, academia has done some work on how to price for the denitrification electricity price. An Yuanyuan etc first constructed a model based on externality and dynamic break-even analysis to calculate denitrification electricity price of a unit [3]; and then she used denitrification electricity price model based on the State's will to pay [4]; after that she also calculated denitrification electricity price for a denitrification project according to the method of operating period electricity price [5]. The limitation of the study above is that they calculate denitrification electricity price based on data of individual typical power plant, however, the coal-fired power plants in China have differences among installed capacity, project property and combustion mode and so on. Therefore, choosing uniform denitrification electricity price as a unified national price does not meet the actual situation.
Based on the problems and limitations of the research above, this article selected randomly 46 denitrification sample from nation and took SCR as a reference technology. Firstly we calculate denitrification electricity price for each sample using the method of operating period electricity price; secondly we use DEA to calculate the relative efficiency of each sample starting from the characteristics of the sample data; at last divide 46 samples into 5 categories according to the relative efficiency in SPSS software. The denitrification electricity price corresponded to the sample with the highest relative efficiency in each category is the benchmark electricity price of this type. This pricing method overcomes the drawback of the papers above, which has certain scientific basis and also conforms to the actual situation.

\section{The Calculation of Denitrification Electricity Price}

This article uses the method of operating period electricity price to measure denitrification electricity price. First establish the calculating model of operating period electricity price, then respectively calculate denitrification electricity price to the randomly selected 46 representative denitrification unit.

\section{A. Denitrification Cash Inflow Model}

1) Denitrification Electricity Price Income: $I_{d}$ represents the income of denitrification electricity price, $Q$ is annual generation capacity, $P$ is denitrification electricity price, $\eta$ is auxiliary power rate, so the income of denitrification electricity price can be described by the following formula:

$$
I_{\mathrm{D}}=P \times Q \times(1-\eta)
$$

2) Invisible Income of Denitrification: Invisible income of denitrification refers to sewage charges of savings duo to denitrification, which is expressed by $I_{y}$. According to the management approach of sewage charge standard promulgated by the State Environmental Protection Administration in 2003, from July 1, 2004, NOx emission charge is $¥ 0.6$ for per 0.95 $\mathrm{kg}$ [6-7]. The actual measurement method is commonly used for the determination of the NOx discharge value for NOx generation mechanism in coal-fired power plant is very complicated. If emissions (the removal amount) is $T$, the sewage charges is calculated as follows: 


$$
I_{y}=0.6 \div 0.95 \times T=0.6316 T
$$

3) Denitrification Cash Inflow Model: If denitrification cash inflow is $C_{i n}$, then

$$
C_{\text {in }}=I_{d}+I_{y}
$$

\section{B. Denitrification Cash Outflow Model}

1) Own capital: In a denitrification project of coal-fired power plant, the own capital ratio is usually $20 \%$. If the total project investment is set as $Z_{V}$, the own capital $C_{b}$ will be $0.2 \mathrm{Z}_{V}$.

2) Operational cost: In the denitrification project of coal fired power plant, operating cost is $C_{o c}$.

3) Financial Cost: Finance cost $C_{F}$ represents the cost to raise funds occurring at the production process. In power project, bank loan is $80 \%$. The formula is:

$$
A=P(A / P, i, n)=C_{F}
$$

of which $A$ is annuity; $P$ is the present value, $i$ is annual interest rate, and $n$ is the pay-back period of loan.

4) Sales Tax and Extra: According to the latest regulations of Chinese tax laws, sales tax and extra $I_{1}$ is $17 \%$ of sales revenue (denitrification electricity price income) $I_{d}$.

$$
I_{1}=I_{d} \cdot 17 \%
$$

5) Income Tax: According to the latest regulations of Chinese tax laws, income tax $I_{2}$ can be calculated by:

$$
\begin{aligned}
& I_{2}=33 \%\left[I_{d}-I_{1}-\left(C_{o c}+C_{f}+I_{4}\right)\right] \\
& I_{4}=Z_{V} \cdot \beta
\end{aligned}
$$

Where $I_{4}$ is depreciation expense, $\beta$ is fixed assets depreciation rate.

6) Accumulation Fund and Welfare Fund: According to the latest regulations of Chinese tax laws, accumulation fund and welfare fund $I_{3}$ can be calculated by:

$$
I_{3}=\left[I_{d}-I_{1}-\left(C_{o c}+C_{f}+I_{4}\right)-I_{2}\right] * 15 \%
$$

7) Denitrification Cash Outflow Model: If denitrification cash outflow is $C_{\text {out }}$, then:

$$
C_{\text {out }}=C_{b}+C_{f}+C_{o c}+I_{1}+I_{2}+I_{3}
$$

\section{Build Pricing Model of Denitrification Electricity Price}

According to the result above, during denitrification operation period, the annual net cash flow is:

$$
\begin{aligned}
& C_{n}=C_{\text {in }}-C_{\text {out }}=I_{d}+I_{y}- \\
& \left(C_{d}+C_{f}+C_{o c}+I_{1}+I_{2}+I_{3}\right)
\end{aligned}
$$

1) Basic Parameters of a Typical Denitrification Device: according to National Development and Reform Commission and Ministry of Construction issued the third edition of Economic evaluation method and parameters of investment project [8], The basic parameters of a denitrification device are shown in TABLE I:

TABLE I Basic Parameters of the Denitrification Device

\begin{tabular}{|c|c|c|c|c|c|}
\hline Parameters & Unit & $\begin{array}{c}\text { Paramete } \\
\text { r values }\end{array}$ & Parameters & Unit & $\begin{array}{c}\text { Parameter } \\
\text { values }\end{array}$ \\
\hline $\begin{array}{c}\text { Auxiliary } \\
\text { power rate }\end{array}$ & $\%$ & 5.2 & $\begin{array}{c}\text { Depreciable } \\
\text { life }\end{array}$ & Year & 15 \\
\hline $\begin{array}{c}\text { Denitration } \\
\text { technology }\end{array}$ & $\%$ & $\mathrm{SCR}$ & Vat rate & $\%$ & 17 \\
\hline Capital ratio & $\%$ & $20 \%$ & Income tax rate & $\%$ & 33 \\
\hline $\begin{array}{c}\text { Repayment } \\
\text { life of loan }\end{array}$ & year & 14 & $\begin{array}{c}\text { Accumulation } \\
\text { fund and } \\
\text { welfare fund }\end{array}$ & $\%$ & 15 \\
\hline $\begin{array}{c}\text { Operation } \\
\text { year }\end{array}$ & year & 20 & $\begin{array}{c}\text { Internal rate of } \\
\text { return }\end{array}$ & $\%$ & 8 \\
\hline
\end{tabular}

2) The Calculation of Net Cash Flow (NCF) in a Life Circle of Denitrification: The formula of net cash flow is:

$$
N P V=\sum_{t=0}^{T}\left[\left(C I_{t}-C O_{t}\right) \times(1+I R R)^{-t}\right]=0
$$

The total amount of the present value of NCF in a denitrification life cycle can be obtained by summing up all the present values at different period:

The 0th year: If the investment capital is $C_{b}$, the present value of $\mathrm{NCF}$ at the 0 th year's should be $-C_{b}$;

From 1st to 14th year: $N C F$ is constant at this period. Assuming $C_{n}$ is the annual $N C F$ from 1 st to 14 th year, the total amount of present value of $N C F$ should be $C_{n} \times(\mathrm{P} / \mathrm{A}, 8 \%, 14)$;

The 15th year. The cash outflow decreases and NCF increases resulting from the decrease of financial cost due to the end of repayment, assuming the increase value of $N C F$ at the 15 th year is $Y_{1}$. It can be seen that from (5) and (8), the income tax, accumulation fund and welfare fund will increase by $\left(33 \% C_{f}+67 \% \times 15 \% C_{f}\right)$; from( $(9)$, we can get $\mathrm{C}_{\text {out }}$ will reduce by $C_{f}$. Compared with that of the period from the 1 st to the 14 th year, $Y_{1}$ can be described by:

$$
Y_{1}=C_{f}-\left(33 \% C_{f}+67 \% \times 15 \% C_{f}\right)
$$

From 16 th to 20 th year. The depreciation life is 15 years, so there is no more depreciation cost at this period, resulting in the decrease of the net cash outflow and the increase of NCF. Assuming the increase value of NCF is $Y_{2}$, the gross of the present value of NCF would be: $\left(C_{n}+Y_{2}\right) \cdot(P / A, 8 \%, 5) \cdot(P / F, 8 \%, 16)$.

After the 16th year (including the 16th year), the depreciation cost $I_{4}$ is 0 . From the (8) and (11), we can get the income tax and accumulation fund and welfare fund will increase by $\left[33 \%\left(C_{f}+I_{4}\right)+67 \% \times 15 \%\left(C_{f}+I_{4}\right)\right]$. Compared to $N C F$ from 1 st to 14 th year, $Y_{2}$ can be described by:

$$
\begin{aligned}
& Y_{2}=\left(C_{f}+I_{4}\right)-33 \%\left(C_{f}+I_{4}\right)-67 \% \times 15 \%\left(C_{f}+I_{4}\right) \\
& =0.5695 C_{f}-0.4305 I_{4}
\end{aligned}
$$


The net cash flows in a life cycle of denitrification are described by Fig. 1:

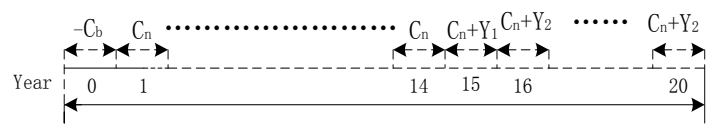

Fig. 1 Diagram of the net cash flow in a life cycle of denitrification calculated separately in different operation period

The NCFs at four different periods were calculated separately, the gross $N P V$ in a whole operation period was the summation of $N P V \mathrm{~s}$ at different periods, as described by (14):

$$
\begin{aligned}
& N P V=-C_{b}+C_{n} \cdot(P / A, 8 \%, 14)+\left(C_{n}+Y_{1}\right) \cdot(P / A, 8 \%, 15) \\
& +\left(C_{n}+Y_{2}\right) \cdot(P / A, 8 \%, 5) \cdot(P / F, 8 \%, 16)=0
\end{aligned}
$$

3) The Pricing Model of Denitrification Electricity Price: Firstly, get the present value factor from the form of present value factor:

$$
\begin{array}{ll}
(P / A, 8 \%, 14)=8.244 & (P / F, 8 \%, 15)=0.313 \\
(P / A, 8 \%, 5)=3.993 & (P / F, 8 \%, 16)=0.292
\end{array}
$$

Putting the expressions of $C_{n}(10), Y_{1}(12), Y_{2}$ (13) and the present value factors(15) into (14), we can get:

$$
\begin{aligned}
& \mathrm{NPV}=-0.2 Z_{V}+\left[I_{d}+I_{y}-\left(C_{b}+C_{f}+C_{o c}+I_{1}+I_{2}+I_{3}\right)\right] \times 8.244 \\
& +\left[I_{d}+I_{y}-\left(C_{b}+C_{f}+C_{o c}+I_{1}+I_{2}+I_{3}\right)+0.5695 C_{f}\right] \times 0.313+\left[I_{d}+\right. \\
& \left.I_{y}-\left(C_{b}+C_{f}+C_{o c}+I_{1}+I_{2}+I_{3}\right)+0.5695 C_{f}-0.4305 I_{4}\right] \times 3.993 \times 0.292
\end{aligned}
$$

Put (1), (2) and (8-10) into the formula above, and simplify it, we can get

$$
P=\left(0.2 Z_{V}-6.201 T+4.75 \mathrm{C}_{f}-3.725 I_{4}+5.591 \mathrm{C}_{o c}\right) /[4.641 Q(1-\eta)]
$$

\section{Calculating the Examples of Denitrification Electricity Price}

This article selects 46 representative denitrification samples, based on the basic data provided by each sample unit and (16), we can get denitrification electricity price of each sample unit. With Excel, the results are shown in TABLE II.

TABLE II Denitrification Electricity Price of 46 Denitrification Samples

\begin{tabular}{|c|c|c|c|c|c|}
\hline Unit & $\begin{array}{c}\text { denitrification } \\
\text { electricity price } \\
\mathrm{P}(\text { yuan/kWh) }\end{array}$ & $\begin{array}{c}\text { denitrification } \\
\text { electricity price } \\
\mathrm{P}(\text { yuan/kWh) }\end{array}$ & & $\begin{array}{c}\text { denitrification } \\
\text { electricity price } \\
\mathrm{P}(\mathrm{yuan} / \mathrm{kWh})\end{array}$ \\
\hline 1 & 0.008161 & 17 & 0.008995 & 32 & 0.010719 \\
\hline 2 & 0.008090 & 18 & 0.011286 & 33 & 0.010921 \\
\hline 3 & 0.008081 & 19 & 0.010607 & 34 & 0.011127 \\
\hline 4 & 0.008087 & 20 & 0.010968 & 35 & 0.008169 \\
\hline 5 & 0.009030 & 21 & 0.010615 & 36 & 0.009665 \\
\hline 6 & 0.009391 & 22 & 0.011121 & 37 & 0.011079 \\
\hline 7 & 0.009210 & 23 & 0.011346 & 38 & 0.011090 \\
\hline 8 & 0.009233 & 24 & 0.010690 & 39 & 0.010163 \\
\hline 9 & 0.009214 & 25 & 0.010344 & 40 & 0.011197 \\
\hline 10 & 0.009187 & 26 & 0.010995 & 41 & 0.011174 \\
\hline 11 & 0.009536 & 27 & 0.010544 & 42 & 0.011213 \\
\hline 12 & 0.009125 & 28 & 0.011053 & 43 & 0.011275 \\
\hline 13 & 0.009121 & 29 & 0.010867 & 44 & 0.011135 \\
\hline 14 & 0.009567 & 30 & 0.011434 & 45 & 0.011142 \\
\hline 15 & 0.009010 & 31 & 0.010710 & 46 & 0.011926 \\
\hline 16 & 0.009117 & & & & \\
\hline
\end{tabular}

\section{Classification Pricing Method of Denitrification Electricity Price}

The classification pricing method can motivate coalfired power plants to improve the running efficiency of environmental protection device and is easy to monitor [9].

\section{A. Calculating Relative Efficiency of Denitrification Sample Based on DEA}

DEA, which is data envelopment analysis, evaluates the relative effectiveness among the decision-making unit (the business or sector of same type) [10]. $C^{2} R$ is the most widely used model, so we introduce the modeling process of $C^{2} R$.

If there are $n$ decision-making unit $\mathrm{DMU}_{\mathrm{j}}$, in which $\mathrm{j}=1,2, \ldots \mathrm{n}$. Each decision-making unit has $m$ kinds of inputs, $s$ kinds of output, $x_{j}=\left(x_{1 j}, x_{2 j}, \cdots, x_{m j}\right)^{T}$ and $y_{j}=\left(y_{1 j}, y_{2 j}, \cdots, y_{s j}\right)^{T}$ respectively refer to inputs and outputs of the $j$ th decisionmaking unit $\mathrm{DMU}_{\mathrm{j}}$. The input-output of $n$ decision-making unit is shown in TABLE III.

TABLE III The Input-output of N Decision-making Unit

\begin{tabular}{|c|c|c|c|c|c|c|}
\hline DMU $_{\mathrm{j}}$ & 1 & 2 & $\ldots$ & $\mathrm{j}$ & $\ldots$ & $\mathrm{n}$ \\
\hline Input 1 & $\mathrm{x}_{11}$ & $\mathrm{x}_{12}$ & $\ldots$ & $\mathrm{x}_{1 \mathrm{j}}$ & $\ldots$ & $\mathrm{x}_{1 \mathrm{n}}$ \\
\hline Input 2 & $\mathrm{x}_{21}$ & $\mathrm{x}_{22}$ & $\ldots$ & $\mathrm{x}_{2 \mathrm{j}}$ & $\ldots$ & $\mathrm{x}_{2 \mathrm{n}}$ \\
\hline$\ldots$ & $\ldots$ & $\ldots$ & $\ldots$ & $\ldots$ & $\ldots$ & $\ldots$ \\
\hline Input $m$ & $\mathrm{x}_{\mathrm{m} 1}$ & $\mathrm{x}_{\mathrm{m} 2}$ & $\ldots$ & $\mathrm{x}_{\mathrm{mj}}$ & $\ldots$ & $\mathrm{x}_{\mathrm{mn}}$ \\
\hline Output 1 & $\mathrm{y}_{11}$ & $\mathrm{y}_{12}$ & $\ldots$ & $\mathrm{y}_{1 \mathrm{j}}$ & $\ldots$ & $\mathrm{y}_{1 \mathrm{n}}$ \\
\hline Output 2 & $\mathrm{y}_{21}$ & $\mathrm{y}_{22}$ & $\ldots$ & $\mathrm{y}_{2 \mathrm{j}}$ & $\ldots$ & $\mathrm{y}_{2 \mathrm{n}}$ \\
\hline$\ldots$ & $\ldots$ & $\ldots$ & $\ldots$ & $\ldots$ & $\ldots$ & $\ldots$ \\
\hline Output $s$ & $\mathrm{y}_{\mathrm{s} 1}$ & $\mathrm{y}_{\mathrm{s} 2}$ & $\ldots$ & $\mathrm{y}_{\mathrm{sj}}$ & $\ldots$ & $\mathrm{y}_{\mathrm{sn}}$ \\
\hline
\end{tabular}

For checking relative effectiveness of DEA, we use the form of Non-Archimedean infinitesimal $\varepsilon$ to construct a linear programming problem corresponding to $\mathrm{DMU}_{\mathrm{j}}[11]$.

$$
\min \left[\theta-\varepsilon\left(e_{1}{ }^{T} S^{-}+e_{2}{ }^{T} S^{+}\right)\right] \quad \text { s.t. }\left\{\begin{array}{l}
\sum_{j=1}^{n} \lambda_{j} x_{j}+S^{-}=\theta x_{0} \\
\sum_{j=1}^{n} \lambda_{j} y_{j}-S^{+}=y_{0} \\
S^{-} \geq 0, S^{+} \geq 0 \\
\lambda_{j} \geq 0, j=1,2, \cdots, n
\end{array}\right.
$$

Of which, $S^{-}=\left(S_{1}^{-}, S_{2}^{-}, \cdots, S_{m}^{-}\right)$is the slack variables of $m$ inputs; $S^{+}=\left(S_{1}^{+}, S_{2}^{+}, \cdots, S_{s}^{+}\right)$is the slack variables of $s$ outputs; $\lambda_{j}(j=1,2, \cdots, n)$ is combination coefficients of $n$ DMU; $e_{1}^{T}=(1,1, \cdots, 1)_{1^{*} m}, e_{2}^{T}=(1,1, \cdots, 1)_{1^{*} s} ; \varepsilon$ is a small positive number, generally $\varepsilon=10^{-5}$.

The optimal solution of the linear programming is $\lambda^{*}$ 、 $\theta^{*} \cdot \mathrm{S}^{*} \cdot \mathrm{S}^{+*}$. Then:

1) If $\theta^{*}=1$ : the decision-making unit DMUj is weakly DEA effective.

2) If $\theta^{*}=1, \mathrm{~S}-=0$, and $\mathrm{S}+=0$ : the decision-making unit $\mathrm{DMUj}$ is DEA effective.

3) If $\theta^{*}<1$ : the decision-making unit DMUj is non-DEA effective. 
We select the above 46 denitrification samples as decision-making unit DMU. To evaluate the relative efficiency of denitrification, the removal amount $(T)$ is more appropriate as output. Proceed with the analysis of the key factors that affect performance and competitive advantage of a project, the total cost is more suitable for input, so we take operating cost $\left(\mathrm{C}_{O C}\right)$, finance cost $\left(C_{f}\right)$ and depreciation expense $\left(I_{4}\right)$ as inputs, adopting DEAP-2.1 software to measure results, which are shown in TABLE IV.

TABLE IV Relative Efficiency of Each Denitrification Project

\begin{tabular}{|c|c|c|c|}
\hline $\begin{array}{c}\text { denitrification } \\
\text { project }\end{array}$ & $\begin{array}{c}\text { Unit capacity } \\
(\mathrm{MW})\end{array}$ & $\begin{array}{c}\text { project nature (new/ } \\
\text { transformation) }\end{array}$ & $\begin{array}{c}\text { relative } \\
\text { efficiency }\end{array}$ \\
\hline 1 & $2 * 1036$ & new & 1.000 \\
\hline 2 & $2 * 1030$ & new & 1.000 \\
\hline 3 & $2 * 1000$ & new & 0.970 \\
\hline$\ldots$ & $\ldots$ & $\ldots$ & $\ldots$ \\
\hline 10 & $2 * 660$ & new & 0.798 \\
\hline$\ldots$ & $\ldots$ & $\ldots$ & $\ldots$ \\
\hline 20 & $2 * 300$ & new & 0.607 \\
\hline$\ldots$ & $\ldots$ & $\ldots$ & $\ldots$ \\
\hline 30 & $2 * 350$ & new & 0.639 \\
\hline$\ldots$ & $\ldots$ & $\ldots$ & $\ldots$ \\
\hline 34 & $2 * 200$ & transformation & 0.424 \\
\hline$\ldots$ & $\ldots$ & $\ldots$ & $\ldots$ \\
\hline 46 & $2 * 220$ & transformation & 0.363 \\
\hline
\end{tabular}

B. Classification Pricing of Denitrification Electricity Price

Because of a larger number of samples, the projects are divided into five categories when cluster analysis to relative efficiency of each denitrification. Select the project that owns the maximal relative efficiency of each category as benchmark, and denitrification electricity price which is corresponding to the benchmarking project is the benchmark price of this category (If there are several projects who all own the maximal relative efficiency, the benchmark price is to average denitration electricity price of those projects). Run SPSS software, and the classification results are shown in TABLE V.

TABLE V The Classification Results of Denitrification Projects

\begin{tabular}{|c|c|c|c|c|c|}
\hline & $\begin{array}{c}\text { The 1st } \\
\text { category }\end{array}$ & $\begin{array}{c}\text { The 2nd } \\
\text { category }\end{array}$ & $\begin{array}{c}\text { The 3rd } \\
\text { category }\end{array}$ & $\begin{array}{c}\text { The 4th } \\
\text { category }\end{array}$ & $\begin{array}{c}\text { The 5th } \\
\text { category }\end{array}$ \\
\hline $\begin{array}{c}\text { The project } \\
\text { involved }\end{array}$ & $1,2,3,4,35$ & 41411 & $33,36-39$ & $18-32$ & $34,40-46$ \\
\hline $\begin{array}{c}\text { Benchmarking } \\
\text { projects }\end{array}$ & $1,2,4$ & 12 & 39 & 31 & 40 \\
\hline $\begin{array}{c}\text { Benchmarking } \\
\text { electricity price } \\
\text { (yuan/ kWh) }\end{array}$ & 0.008113 & 0.009125 & 0.010163 & 0.01071 & 0.011197 \\
\hline
\end{tabular}

According to the above analysis of classification results, excluding the individual special units, our classification pricing recommendations are given as follows:

1) Denitrification electricity price of the new $1000 \mathrm{MW}$ unit is 0.008113 yuan / $\mathrm{kWh}$.

2) Denitrification electricity price of the new $600 \mathrm{MW}$ unit is 0.009125 yuan/ $\mathrm{kWh}$.
3) Denitrification electricity price of the transformed $600 \mathrm{MW}$ unit is 0.010163 yuan/ $\mathrm{kWh}$.

4) Denitrification electricity price of the new $300 \mathrm{MW}$ unit is 0.010710 yuan $/ \mathrm{kWh}$

5) Denitrification electricity price of the transformed $300 \mathrm{MW}$ and below $300 \mathrm{MW}$ unit is $0.011197 \mathrm{yuan} / \mathrm{kWh}$.

\section{Conclusion}

It is of great significance to encourage coal-fired power plants for NOx pollutants. Under the current electric power system and environmental protection policy, it is necessary to implement denitrification electricity price for stimulating coalfired power plant to put into denitrification device as required. And the rationality of the denitrification electricity price level is the key to determine the effectiveness of this policy. The methods are more persuasive because they are realistic and take factors into account comprehensively. Scientific level of denitrification electricity price is an incentive for coal-fired power plants to install denitrification device, and it is also significant to achieve environmental emission reduction targets; at the same time, the classification results proposed by this article can offer reference for future denitrification project pricing.

\section{References}

[1] Wang C.H, "The introduction of China's NOX pollution situation and the development and standards of the management technology," Mach. Ind. Stand. and Qual, vol. 8, no. 3, pp. 20-21, 2008.

[2] Yang D, Xu H, "SCR flue gas denitrification technology and its application in coal-fired power plants," Electric power environmental protection, vol. 1, pp. 49-51, 2007.

[3] Zhou J.G, An Y.Y, Duan S.L, Zhao Y, "The research on denitrification electricity price based on externality and dynamic break-even analysis in coal-fired power plants," Power system protection and control, vol. 38, no. 8, pp. 85-91, 2010.

[4] Zhou J.G, Cui B, Zhao Y, "The research on denitration electricity price based on externality and national willingness to pay," Technical and economic, vol. 29, no. 5, pp. 48-53, 2010.

[5] Zhou J.G, Zhou C.J, Zhao Yi, "The study on denitrification electricity price compensation based on the method of operating period electricity price in coal-fired power plant," East China Electric Power, vol.38, no. 12, pp.1960-1963, 2010.

[6] GB13223-2003, "Emission standard of air pollutants for coal-fired plants", 2003.

[7] State Development Planning Commission, Ministry of Finance, The China Environmental Protection Agency, State Economic and Trade Commission, "The management approach of Sewage charges' collection standard", 2003.

[8] National Development and Reform Commission and Ministry of Construction, "Construction project economic evaluation methods and parameters", 2006.

[9] Li X.P, "The research of desulfurization and denitration electricity price compensation mechanism for coal-fired plants," Dissertation, North China Electric Power University, 2009.

[10] Gao Y.C, "The research on the relative efficiency evaluation of regional economic based on DEA," Statistics Education, vol. 112, no. 1, pp. 3-8, 2009.

[11] Li X.Y, "Benchmarking theory and application based on data envelopment analysis," Dissertation, Nanjing University of Science and Technology, 2010. 